\title{
Yıkıma Doğru Bir İmparatorluğun Salgınlarla İmtihanı: II. Meşrutiyet Dönemi Örneği
}

\author{
M. EMİN ÇAYCİ \\ emincayci@kocaeli.edu.tr \\ ORCID ID: 0000-0003-0381-1936
}

\author{
ABİDİN ÇEVİK* \\ abidin.cevik@kocaeli.edu.tr \\ ORCID ID: 0000-0001-5459-2935
}

Öz: Osmanlı Devleti'nin son dönemi ekonomik krizler, savaşlar ve iç karışıklkklarla geçmiş, bunun yanı sira salgın hastalıklarla da mücadele edilmiștir. İran ve Kafkasya üzerinden gelen ticaret yolları, kutsal topraklardan dönen ziyaretçiler, Antalya, İstanbul, İzmir ve Trabzon gibi liman kentlerine gelen gemiler, hastalikların yayılmasında etkili olmuștur. Salgınların önlenmesinde karantina uygulaması, sinırların kapatılması, hijyen önlemleri gibi yöntemler kullanılmıștır. Tıbbi imkânlar ve genel ekonomik manzara mücadelenin sağlıklı yapılmasını engellemiștir. Farkh yöntemlerle sürdürülen mücadele, basında ve siyasal düzlemde çeșitli eleştirilere uğruyordu. Alınan önlemler eğitim, ulaşım ve ticaret gibi alanlarda aksamalara neden oluyor, bu durum eleștirilere yol açıyordu. Osmanlı arșiv belgelerinin ana kaynak olarak kullanıldiğı bu çalıșmada, II. Meșrutiyet dönemi salgınları ile yerel ve merkezi yönetimlerin aldığı önlemler anlatılmaya çalıșllmıștır. Osmanlı arșiv belgelerinin temel kaynak olarak kullanıldiğı bu çalışmada, II. Meşrutiyet dönemi salgınlarının toplumsal etkilerini, yerel ve merkezi yönetimin aldığı tedbirler anlatılmaya çalışılmıştır.

Anahtar kelimeler: Salgın hastalıklar, Kolera, Veba, II. Meşrutiyet, Osmanlı İmparatorluğu

\section{Giriş}

Toplumlar, tarih boyunca sel, deprem, kuraklık gibi pek çok yıkıcı doğa olayına maruz kaldıkları gibi salgın hastalıklarla da uğraşmak zorunda kalmışlardır. Salgın hastalıklar, yalnız insan hayatını değil toplumların siyasi ve demografik yapılarını derinden etkileyen kitlesel kayıplara yol açmıștır. Bunlardan biri günümüz Türkiye'sinde "veba", Osmanlı döneminde "veba" ya da "taun" olarak bilinen ve Avrupa dillerindeki "plague" ya da "black death"e (kara ölüm) karşılık gelen salgın hastalıktır. Veba farklı tarih ve coğrafyalarda büyük insan kayıplarına yol açmıştır. Örneğin, 1347'de Avrupa'yı kasıp kavuran veba, Avrupa nüfusunun üçte birinin ölümüne neden olmuştur. Hastalık, etkisini yitirdikten sonra da kıtlığa, açlıktan ölümlere ve yeni sağlık sorunlarına yol açmıştır. Veba sonrası ortaya çıkan

\footnotetext{
* Öğr. Gör., Kocaeli Üniversitesi, Atatürk İlkeleri ve İnkılap Tarihi Bölümü.

${ }^{* *}$ Öğr. Gör. Dr., Kocaeli Üniversitesi, Atatürk İlkeleri ve İnkılap Tarihi Bölümü.
} 
tablo, aynı zamanda toplumsal ve ekonomik ilişkilerin dönüşümünü de hızlandırmıştır. ${ }^{1}$ Salgın nedeniyle çalışma hayatı sekteye uğramış, iş gücüne olan yoğun talep ücretleri aşırı derecede yükseltmiştir. Bu nedenle 1350 Emekçiler Yasası gibi düzenlemelerle çalışma yaşamında köklü değişimlere gidilmeye çalışılmıştır. ${ }^{2} 14$. yüzyılda Avrupa'da yaşanan bu salgının benzerleri ilerleyen dönemlerde de görülmüştür.

Hastalığın en önemli yayılma nedeni fare ve pire gibi hayvanlardır. Özellikle liman kentlerinde, yük gemileriyle taşınan fare ve pireler hastalığı hızlı bir şekilde yayıyorlardı. Pirelerin bu hastalıktaki rolü uzun süre anlaşılamadığından yayılmasını önlemek de zor olmuştur. Hızlı ve kolay bir biçimde kente bulaşan veba, toplu ölümlere yol açıyor, sokaklara taşan insan cesetleri hayvanlar tarafından parçalanıyor, böylece hastalığın yayılma hızı artıyordu. ${ }^{3}$

Veba, yalnızca halkı değil Kastilya Kralı XI. Alfonso, İngiltere Kralı III. Edward'ın kızı Prenses Joan gibi soyluları da öldürmüştür. ${ }^{4}$ Ancak vebanın en büyük yıkımı yoksullar üzerinde gerçekleşmiştir. Yoksul halkın büyük kısmı rutubetli, güneş görmeyen, her türlü mikrobun yaşamasına müsait konutlarda yaşıyordu. Artan kayıplar karşısında tedbir almak zorunda kalan yönetimler, domuzların sokaklarda gezmesini yasaklamak, lağım sistemleri yapmak gibi tedbirler alarak salgınla mücadele etmeye çalışmıştır. ${ }^{5}$

Veba dişında tifüs, çiçek, tifo, difteri, boğmaca gibi pek çok başka hastalık da Avrupa kıtasında insan ölümlerine yol açmıştır. Ülkeler arası yoğun ticaret nedeniyle bu hastalıklar Avrupa dışına da yayılmış, bağışıklığı olamayan toplumları zaman zaman felaketlere sürüklemiştir. Örneğin İspanyolların taşıdığg çiçek mikrobu, bu hastalığa bağışıklığı olmayan Güney Amerika halklarında kitlesel ölümlere neden olmuştur. ${ }^{6}$

Veba salgını, Bizans, Selçuklu ve Osmanlı İmparatorluğu dönemlerinde Anadolu'da da görülmüştür. İmparator Justinianos zamanında VI. yüzyılda, Akdeniz sahilleri ile Ortadoğu'da çıkan büyük bir veba salgını Anadolu'ya yayılmış, pek çok kişinin ölümüne sebep olmuştur. Yine V. Konstantin ve II. Nikephoros Phokas dönemlerinde İstanbul'u etkileyen büyük veba salgınları görüldüğü bilinmektedir. ${ }^{7}$ Selçukluların Anadolu'da hâkimiyet kurdukları ve Haçlı Seferleri’nin ortalığı kasıp kavurduğu dönemde veba salgınları etkili olmuştur. 13. yüzyıldaki Moğol istilası

\footnotetext{
${ }^{1}$ Leo Huberman, Feodal Toplumdan Yirminci Yüzyıla, çev., Murat Belge, İstanbul: İletişim Yayınları, 1995, s.60-63.

${ }^{2}$ Robert Castel, Ücretli Çalışmanın Tarihçesi, çev., Işıı Ergüden, İstanbul: İletişim Yayınları, 2019, s.74-75.

${ }^{3}$ Kemal Özden ve Mustafa Özmat, "Salgın ve Kent: 1347 Veba Salgınının Avrupa'da Sosyal, Politik ve Ekonomik Sonuçları”, İdeal Kent Dergisi, 12 (2014), s.66-67.

${ }^{4}$ Tolgahan Karaimamoğlu, "Kara Ölüm Veba Salgını ve Ortaçağ İngiltere'sine Etkileri”, Akademik Sosyal Araştırmalar Dergisi, 37, (2016), s.593.

${ }^{5}$ Server Tanilli, Yüzyılların Gerçeği ve Mirası İnsanlık Tarihine Giriş Ortaçă̆, İstanbul: Cem Yayınları, 1995, s.492.

${ }^{6}$ Castel, Ücretli Çalışmanın, s.390.

${ }^{7}$ Feda Şamil Arık, "Selçuklular Zamanında Anadolu'da Veba Salgınları”, A.Ü. Tarih Araştırmaları Dergisi, XV/26 (1991), s.38-40.
} 
sırasında da vebanın görüldüğ̈̈ kayıtlara geçmiştir. Kayıtlara göre salgınlar kimi zaman aylarca sürmüş ve yaşam koşulları üzerinde olumsuz etki bırakmıştır. ${ }^{8}$

Veba salgını Osmanlı Devleti'nin erken dönemlerinden itibaren de Anadolu'da etkili olmuştur. Osmanlının ikinci padişahı Orhan Gazi’nin ölümünün veba kaynaklı olduğu yönünde güçlü rivayetler vardır. ${ }^{9} 1429$ 'da Bursa'da başlayan veba salg1nında halkın yanında Emir Buharî, Molla Fenarî, Emir Süleyman'ın oğlu Orhan Bey, Hacı İvaz Paşa gibi dönemin önemli isimlerinin de hayatını kaybettiği görülür. ${ }^{10}$ Yine 1455-1475 yılları arasında İstanbul'da etkili olan veba salgınları nedeni ile Fatih Sultan Mehmet'in şehirden ayrıldığı ve Balkanlarda sürekli yer değiştirerek kendi önlemini aldığı bilinmektedir. ${ }^{11}$ Salgın imparatorluk ekonomisi üzerinde yıkıcı etkiler yaratmış, geniş halk kitleleri yoksullukla mücadele etmek zorunda kalmıştır. 1500'lü yılların başında ortaya çıkan ve yaklaşık üç yıl süren veba, Anadolu'nun çeşitli yerlerinde kıtlıklar yaşanmasına neden olmuştur. Solakzade Tarihi'nde halkın elli altmış dirhem (160-190 gram) ekmeği 1 Osmaniye’ye aldığı zaman mutlu olduğu, kıtlık ve pahalılık yüzünden insanların zayıf düştügü, hatta Bolu tarafında yaşayanların iki aydan fazla ekmeksiz geçinip ot otladıklarını nakledilmektedir. ${ }^{12}$

Başkent İstanbul'da 1539, 1573, 1576, 1578, 1591-1592 ve 1596 yıllarında da veba salgınları yaşanmıştır. Salgınlar, XVII. yüzyıldan XIX. yüzyılın başlarına kadar kimi zaman şiddetli kimi zaman daha hafif şekilde etkili olmuştur. ${ }^{13}$ İstanbul, 17001850 arasında geçen 150 yılın neredeyse üçte ikisinde veba salgınına maruz kalmıştır. ${ }^{14}$ Salgının genel olarak nisan ayında başlayıp ağustos ayı gibi zirve yaptığı ve ekim ayında bittiği kaydedilmiştir. İklim koşullarının bu aylarda başta ticaret olmak üzere nüfus hareketine uygun olması, salgının şiddetini ve yayılma hızını artırmıştır. Tarihi kayıtlar özellikle İran ve Mısır'dan gelen kervan ve gemilerin hastalığın taşınmasında etkili olduğunu ortaya koymaktadır. Veba İstanbul dışında İzmir, Halep, Basra ve Bağdat gibi ticaretin yoğun olduğu kentlerde de görülmüştür. ${ }^{15}$ Yine 1910 yılında Antalya'da ortaya çıkan vebanın, her sene İskenderiye ve Dimyat'tan gelen gemiler vasıtasıyla yayıldığı tespit edilmiştir. ${ }^{16}$ Veba salgını 19. yüzyılın ilk yarısında yıkıcı bir dalga ile yeniden Osmanlı topraklarında görülmüşse de hızlı bir şekilde etkisini kaybetmiştir.

Osmanlı topraklarında etkili olan diğer bir salgın hastalık da "kolera"dır. Vibrio cholerae adlı bir bakteri türü olan, kirli içme suları ve yiyeceklerle bulaşan kolera

\footnotetext{
8 Arık, "Selçuklular Zamanında", s.44-49.

${ }^{9}$ Necdet Sakaoğlu, Bu Mülkün Sultanları, İstanbul: Alfa Yayınları, 2015, s.41.

${ }^{10}$ Hikmet Özdemir, Salgın Hastalıklardan Ölümler 1914-1918, Ankara: Türk Tarih Kurumu Yayınları, 2005, s.23.

${ }^{11}$ Nalan Turna, "İstanbul'un Veba ile İmtihanı: 1811-1812 Veba Salgını Bağlamında Toplum ve Ekonomi", Studies of The Ottoman Domain, 1/1 (2011), s.16.

${ }^{12}$ Solakzade Tarihi, İstanbul: Mahmutbey Matbaas1, 1297, s.318.

${ }^{13}$ Mesut Ayar, “Osmanlı Devleti'nde Kolera Salgını: İstanbul Örneği 1892-1895”, Doktora Tezi, Marmara Üniversitesi, 2005, s.2.

${ }^{14}$ Suraiya Faroqhi, Osmanlı İmparatorluğunda Yollara Düşenler, İstanbul: Kitap Yayınları, 2016, s.292.

${ }^{15}$ Suraiya Faroqhi, “Krizler ve Değişim 1590-1699”, Osmanl İmparatorluğu’nun Ekonomik ve Sosyal Tarihi 2, der., Halil İnalcık ve Donald Quataert, İstanbul: Eren Yayınları, 2004, s.571.

${ }^{16}$ DH. MUI. 3-19.
} 
oldukça hızlı yayılan bir hastalık olarak bilinmektedir. Genellikle, bağırsaklara yerleşen bakteri insan dışkısının sulara karışması yoluyla yayılmaktayd $1 .{ }^{17} 1821$ yılında Rusya'dan Anadolu'ya taşınan kolera mikrobu, önce Doğu Anadolu'da, daha sonra zamanla Irak ve Suriye'de baş göstermiştir. Savaşlar, Hindistan üzerinden gelen ve Türkiye'deki limanlara uğrayan ticaret gemileri ya da Medine'den dönen hacılar da hastalığın taşınıp yayılmasında önemli roller oynamışlardır. ${ }^{18}$

Aynı anda ve aynı yerde birlikte de görülebilen bu hastalıklar toplu ölümlere, dolayısıyla da sosyal trajedilere yol açmışlar, ekonomik yapıyı bozarak toplumsal ilişkilere zararlar vermişlerdir.

Devletler 19. yüzyıldan itibaren salgınlara karşı etkili yöntemler geliştirmeye çabalamışlardır. Avrupa ve Amerika'da pek çok uluslararası sağlık konferansı düzenlenmiş, buralarda halk sağlığının korunmasına yönelik kararlar alınmıştır. Karantina kurallarının belirlenmesi, aşı ve serumların sınıflandırılması, limanlarda sağlık şartlarının iyileştirilmesi, bazı hastalıkların ortaya çıktığı anda bildirilme zorunluluğu gibi günümüzde salgın hastalıkların yayılmasını önleme amaçlı kullanılan yöntemler bu süreçte tartışılmıştır. ${ }^{19} \mathrm{Bu}$ yöntemler Osmanlı Devleti tarafından da gücü ve imkânları ölçeğinde kullanılmaya çalışılmıştır. Salgın hastalığın tipine göre hastanelerin kurulması veya var olan hastanelerde salgına yönelik özel yerler yapılması bu kapsamda değerlendirilebilir. Yine hastalığa yakalanan kişilerin ücretsiz tedavisi, karantina, tebhir (buharla dezenfekte), etüv (buhar) makinesi kullanımı gibi yöntemler de uygulanmıştır. Karantina İdaresi, Tathirat (temizlik) Komisyonu, Meclis-i Umur-1 Sıhhiye gibi kurumlar vasıtasıyla da salgının yayılmasının önüne geçilmeye çalışılmıştır. Ayrıca, limanlar ve gümrüklerin yakınlarına tahaffuzhane denilen karantina yapıları inşa edilerek yurt dışı kaynaklı salgınların ülkeye girişinin engellemesi hedeflenmiştir. Salgınların görüldüğü bölgelerde altyapı sorunları çözülmeye çalışılmış, hijyen kurallarının sıkı şekilde uygulanmasına yönelik önlemler alınmıştır. Özellikle içme sularının temizliğine ve kanalizasyon sisteminin geliştirilmesine ağırlık verilmiştir. Devletin tüm bu çabaları, ekonomik sıkıntılar ve bitmek bilmeyen savaşların yarattığı yıkımlar yüzünden sürekli akamete uğramıştır.

\section{Meşrutiyet Dönemi Salgın Hastalıklar ve Alınan Tedbirler}

İmparatorluğun kendi sınırları dâhilinde ortaya çıkan, zaman içerisinde sıradan kabul edilen ve öldürme etkisi uzun zamana yayılan veba, kolera, tifüs, verem, çiçek, sıtma gibi geniş toplum kesimlerini etkileyen hastalıklar meselesi İmparatorluk yöneticilerinin de gündemini meşgul etmiştir. Meclis-i Sıhhiye İkinci Reisi Dr. Esat Bey, 1911 tarihli Meclis-i Mebusan konuşmasında bu konuyu derinlemesine analiz etmiştir. Doğum sonrası yaşanan ölümlerin oranları konusuna değinen Esat Bey, Eskişehir'de son 3 yılda ölüm sayısının doğum sayısından 3000 fazla olduğunu, bunun da sıtmadan kaynaklandığını belirmiştir. Böyle bir oranın nüfusun

\footnotetext{
${ }^{17}$ Ayar, Osmanlı Devleti'nde, s.3.

${ }_{18}^{18}$ Donald Quataert, “19. Yüzyıla Genel Bakış: Islahatlar Devri 1812-1914”, Osmanlı İmparatorluğu’nun Ekonomik ve Sosyal Tarihi 2, der., Halil İnalcık ve Donald Quataert, İstanbul: Eren Yayınları, 2004, s.911-912. ${ }^{19}$ Özgür Topkaya, "Sosyal Politika Bağlamında Dünyada Sağlık Politikalarının Tarihsel Gelişimi”, Süleyman Demirel Üniversitesi İktisadi ve İdari Bilimler Fakültesi Dergisi, 21/2 (2016), s.707.
} 
artışına imkân vermeyeceğini vurgulayan Esat Bey, Avrupalıların "hayat eşit sıhhat; sihhat eşit servet" dediğini, sihhatin servetten önce geldiğini savunduğunu belirttikten sonra hastalıklara dikkat çeker:

"(birincisi veba ve kolera) bu gibi hariçten gelen hastalıklar nüfus-ı memleketi mühim zayiata duçar edebilir. Buna karşı adeta nasıl ki hariçten gelecek düşmana ordumuz, kalemiz, toplarımız, tüfeklerimiz, süngülerimiz lazımsa, cihet-i sıhhiyede de böyle hariçten gelecek gayr-i mer’i (gözle görülmez) bir düşmana karşı vesait-i fenniye (bilimsel araçlar) lazımdır. Bunlardan min küll-il-vücuh (her yönden) memleketimiz mahrumdur... İkincisi bunu daha tali derecede bırakacak kadar büyüktür, o da dâhili olan emrazdır (hastalıklar). Bunların içinden birkaç tanesini arz edeyim: Bir tanesi, en başta sıtma; ikincisi frengi, üçüncüsü verem, dördüncüsü çiçek; beşincisi kuşpalazı ve tifo gibi emraz-1 müstevliye-i içtimaiyedir (salgın hastalıklardır). Bendenizce bu emrazın ehemmiyeti, hariçten gelen kolera ve vebadan büyüktür. Zira bu hastalıklar, ara sıra gelir, muayyen bir müddet zarfında zail olur ve defolur gider. Hâlbuki öbürleri, daima içimizde, memlekette mevcuttur. İstatistiğimiz olmadığı cihetle vefiyatın (ölümlerin) miktarını bilmiyoruz. Eğer böyle bir istatistiğimiz mevcut olsa, zannederim ki hâsıl olacak neticeden tüyler ürperir efendim."20

Esat Bey'in konuşması Osmanlının son dönemindeki salgın hastalık meselesinin özeti gibidir. Devlet, kolera ve vebayla mücadeleyi imkânlar ölçüsünde sürdürse de, onca sosyal, siyasal ve ekonomik sıkıntı içinde salgınlarla başarılı şekilde mücadele ettiğini söylemek zordur.

Esat Bey’in sözünü ettiği istatistikler kendisini doğrular niteliktedir. Şehremaneti Sıhhiye Müdürlüğü tarafından 1915'te yayınlanan sıhhi istatistiklerde özellikle verem hastalığının ölüm oranı dikkat çekmektedir.

Tablo 1. 1908-1914 Yılları Arasında İstanbul'da Gerçekleşen Genel Ölüm Sayısı ile Salgın Hastalıktan Ölüm Mukayese Cetveli ${ }^{21}$

\begin{tabular}{|c|c|c|c|c|c|c|c|c|}
\hline Yll &  & $\begin{array}{l}\frac{5}{0} \\
\text { गे } \\
د\end{array}$ &  & $\begin{array}{l}\frac{U}{\Xi} \\
\stackrel{\Xi}{\mathbb{N}} \\
\mathbb{N}\end{array}$ & $\begin{array}{l}\vec{N} \\
\vec{N}\end{array}$ & $\frac{\bar{s}}{\stackrel{0}{0}}$ & .心 & $\frac{a}{\frac{a}{2}}$ \\
\hline 1908 & 16.741 & 2804 & 648 & 136 & 14 & 68 & 349 & - \\
\hline 1909 & 16.630 & 2863 & 513 & 76 & 39 & 45 & 49 & - \\
\hline 1910 & 11.703 & 2838 & 371 & 112 & 86 & 60 & 1 & 798 \\
\hline 1911 & 17.984 & 3055 & 438 & 183 & 167 & 74 & 221 & 1583 \\
\hline 1912 & 21.662 & 2886 & 459 & 548 & 188 & 102 & 917 & 1277 \\
\hline 1913 & 18.538 & 2639 & 614 & 617 & 180 & 97 & 400 & 238 \\
\hline 1914 & 17.714 & 3078 & 429 & 105 & 69 & 64 & 45 & 4 \\
\hline
\end{tabular}

${ }^{20}$ MMZC, C: 6, D: 1, İ: 102, s.690.

${ }^{21}$ Dersaadet 1330 Senesine Mahsus Sıhhi İstatistiklerdir, Şehremaneti Sıhhiye Müdüriyeti, Dersaadet, 1331: 26. 
$\mathrm{Bu}$ dönemin en korkulan hastalığı koleradır. Tehlike, Osmanlı sınırlarına ulaşır ulaşmaz devlet önlemler almaya girişmiştir. Sınır komşusu olan ülkelerdeki büyükelçilikler, herhangi bir salgın hastalık durumunda Hariciye Nezareti'ne hızlı bir şekilde bildirilmesi konusunda sürekli uyarılmışlardır. ${ }^{22}$ Özellikle Rusya'da yaşanan salgınlar deniz yolu ile Trabzon, kara yolu ile Erzurum gibi kentlere taşınmaktaydı. Rusya topraklarında yaşayan Müslümanların hac güzergâhı olarak Osmanlı topraklarını kullanmaları, tehlikeyi daha da artırıyordu. 1908 sonbaharında Petersburg'da 24 saat içinde 2420 kolera vakasının tespit edildiği ve bunların 760'ının öldügü bildirilmiştir. Bu salgında ölümler, hastalık belirtisinden hemen sonra başlamıştır; bu nedenle tehlikenin çok daha büyük olduğu kaydedilmektedir. Ayrıca kış mevsiminin yaklaşması ve Rusya'daki hacıların dönmeye başlaması yüzünden önlemlerin artırılması ve sınırların kapatılması gerektiği belirtilmektedir. ${ }^{23}$

Rusya'daki 1908 salgını hızla yayıldığı için kontrolünün çok zor olduğu bilinmektedir; bu nedenle göçmen tehlikesine karşı önlemler alınması gerekmiştir. Örneğin, Rusya'dan Kavak Tahaffuzhanesi'ne (karantina yeri) gelen Çariçe isimli gemide 113 kişi olduğu ve henüz sayısı bilinmeyen insanın da Osmanlı topraklarına gelmek üzere yola çıktığı haberi alınmıştır. Bunların özel bir vapur ile Beyrut Tahaffuzhanesi'ne gönderilmesine karar verilmiş, Osmanlı sınırlarına gelmeyi planlayanların hareket tarihlerinin ertelenmesi gerektiği Petersburg'daki elçiliğe bildirilmiştir. ${ }^{24}$ Ayrıca bir şekilde gelenlerin beş gün süreyle karantina altında tutulup sağlık kontrollerinden geçirilmesi zorunlu kılınmıştır. ${ }^{25}$

Salgınlardaki bir diğer temel sorun da, kaçak yollarla imparatorluk geçişler olmasıdır. Dönemin koşulları, bu geçişleri önlemeyi zorlaştırmıştır. Yine de, imkânlar ölçüsünde Rize ve Sürmene kıyılarında sürekli kolcu kayıkları gezdirildiği, askeri gambotlar (küçük savaş gemisi) ile devriye atılarak olası kaçak girişlerin önlenmeye çalışıldığı görülmektedir. Ayrıca ek tedbir olarak Mesud Vapuru da bölgeye gönderilmiş ve Sürmene ile Hopa arasında kontroller artırılmıştır. ${ }^{26}$ Aynı şekilde, 1910 yılında koleranın artış gösterdiği Rusya ve Kafkasya'dan gelecek muhacirlerin Osmanlı topraklarına girişinin engellenmesi için harekete geçildiği bilinmektedir. ${ }^{27}$

Salgınların imparatorluğa yayılmasını hızlandıran temel faktörlerden biri de hac ve umre ziyaretleridir. Hacıların, Mekke ve Medine'de kaptıkları hastalıkları imparatorluğun dört bir yanına hızla yaydıkları bilindiği için devlet önlemler konusunda dikkatli hareket ediyordu. Örneğin, 1908 yılında Mısır Sıhhiye Meclisi, Suriye üzerinden dönecek hacıları taşıyan gemilerin önce İskenderiye'de 10 gün karantina altında tutulacağ yönünde karar almış, bununla da yetinmemiş, ardından hacıları taşıyan hiçbir geminin limanlara almayacağı kararını duyurmuştur. Bunun üzerine Osmanlı Sıhhiye Nezareti, Sadrazamlığa bir yazı göndermiştir. Yazıda Medine'den kara yoluyla dönen hacıların 12 gün Medayin-i Salih'de (Medine'nin ku-

\footnotetext{
${ }^{22}$ HR.SFR.04. 843-26.

${ }^{23}$ DH.MKT. 2617-68.

${ }^{24}$ DH.MKT. 2617-64.

${ }^{25}$ DH.MKT. 2615-50

${ }^{26}$ DH.MKT. 2650-93.

${ }^{27}$ HR. İD. 10-63.
} 
zeyinde bir bölge), ardından 3 gün de Beyrut Tahaffuzhanesi'nde karantinada tutulduğunu, tedbir ve temizlik işlemleri uygulandıktan sonra durumlarının beş gün boyunca gözlendiğini ve hiçbir hastalık belirtisi göstermediklerinin anlaşıldığ belirtilmiştir. ${ }^{28}$ Suriye'de ise, hastalık belirtisi olmadığ için Mısır Sıhhiye Meclisi'nin kararının değiştirilmesi konusunda görüşmeler yapılması istenmiştir. Hac dönüşüne denk gelen böyle bir dönemde herhangi bir hastalığın görülmemesi, o dönem için bir şanstır. Ancak 1910 yılında hac dönüşleri sırasında kolera ve veba vakaları rapor edilmiştir. ${ }^{29}$ Beyrut'a hastalıklı vapurlarla gelen Rusya hacılarında kolera vakasına rastlanmış, bunun üzerine hacılar Beyrut Karantinahanesi'nde bekletilmiş, gerekli fenni tedbirler alındıktan sonra ancak işlemleri yapılmıştır. ${ }^{30} 1912$ yılında ise, Mekke ve Medine'den dönen kafilede koleraya bağlı olarak 32 kişinin hayatını kaybettiği bildirilmiştir. ${ }^{31}$

Tüm bu uğraşlar zaten sorunlu olan ekonomik koşulları da etkilemiştir. Farklı bölgelerde ortaya çıkan ve imparatorluk sınırlarında yayılan salgınları önleme çabaları hazineye büyük yük getirmekteydi. Sadrazam İbrahim Hakkı ve Dâhiliye Nazırı Halil imzasıyla Meclisi Mebusan'a sunulan bir kanun teklifi ile hacıların rahatını sağlamak ve salgın hastalık tehditlerine karşı sıhhi tedbirler almak için Hicaz Sıhhiye Meclisi aracılığ ile kutsal topraklara giden her kişiden "Hicaz'a mahsus tedabir-i sıhhiyye resmi" adıyla 10 kuruş vergi alınacağ belirtilmiştir. ${ }^{32}$ Bölgedeki karantina ve tedavi masrafları sadece hazineden gönderilen para ile halledilemediği için bu yöntemin uygulanması Meclis tarafından kabul edilmiştir.

Karantina ve temizlik, salgınların kontrol altına alınmasında ilk başvurulan en etkili mücadele yöntemiydi. Bu yönde öncelikle sınırlarda önlem alınıyor, böylece dışarıdan gelecek vakaların önü kesilmeye çalışılıyordu. Girişler sınır ve liman bölgelerinde kurulan tahaffuzhaneler ve tebhirhanelerle (buharla dezenfekte yerleri) denetleniyordu. Yine Karadeniz, Akdeniz ve Kızıldeniz'de önemli geçiş noktalarına karantinahaneler kuruluyordu. ${ }^{33}$ Öte yandan, İstanbul'un Gedikpaşa, Tophane, Üsküdar gibi bölgelerindeki atıl durumdaki tebhirhaneler yeniden düzenlenerek işler hale getirilmiş ve yurt dışından hijyen için kullanılacak cihazlar ve ilaçlar sipariş verilmiştir. ${ }^{34} 1909$ yılında Dâhiliye Nezareti, her vilayete seyyar bir etüv makinesi ile pülverizatör (ilaçlama makinesi) satın alınmasını kararlaştırmıştır. ${ }^{35}$ Ancak belediye bütçelerinden ödenmesi istenen cihazları her vilayetin alması mümkün olmamıştır. Bu gerçek, sonraki dönemlerde söz konusu vilayetlerde yaşanan vakalarla ilgili yazışmalara da yansımıştır.

Özellikle kolera konusunda, hastane ve karantina merkezlerinin oluşturması konusunda -yetersiz bile olsa- yetkililerin çabaları arşiv belgelerine ve meclis zabıtlarına da yansımıştır. Bu çabanın, diğer hastalıklar için gösterilmediği görülmekte-

\footnotetext{
${ }^{28}$ A_MTZ.05 19-112.

${ }^{29}$ MMZC. C: 2, D: 1, İ: 29: s.293.

${ }^{30}$ DH.İD. 50-6.

${ }^{31}$ BEO. 4103-307685.

${ }^{32}$ MMZC. C: 5, İ: 75, D:1, s.116..

${ }^{33}$ MMZC. C: 5, D: 1, İ:83: s.432-433.

${ }^{34}$ MMZC C: 1, D: 1, İ: 6, s.126.

${ }^{35}$ DH HMŞ. 14-26.
} 
dir. Örneğin, 1911 yılında Konya Mebusu Mehmet Emin imzasıyla verilen bu konudaki bir önerge tartışılmaya bile gerek görülmeden reddedilmiştir. ${ }^{36}$

"Meclis-i Mebusan Riyaset-i Celilesine

Vilayatı (şehirleri) çiçek, verem, frengi, sıtma gibi bir takım mühim hastalıklar daima taht-1 tehditte bulundurmakta ve maatteessüf nüfusumuzu günden güne tenkis etmekte (azaltmakta) olduğundan, her livaya hiç olmazsa 30'ar yataklı birer hastahane yaptırmak ve seyyar aşı memurları ve tabipler tayin olunmak misillu (benzeri) tedabir-i ciddiyeye tevessül olunarak, tevessuuna meydan verilmemesini hükümete tebliği teklif ederim.”

Öneri reddedilince Çorum Mebusu Ali Osman Bey "Efendim bu tahrir pek mühimdir, reddolunacak bir şey değildir. Dahiliye Nezaretine havale olunsun.” diye itiraz etmiş ancak bu itiraz meclis başkanı tarafından kabul edilmemiştir.

Mecliste yaşanan bu tartışmaların benzerleri çeşitli vesilelerle dönemin basınına da yansımıştır. Gazeteler yönetimin başarısızlıklarını ya da yanlış uygulamalarını haber yapmıs, halktan gelen şikayet telgraflarını yayınlamışlardır. Kimi zaman duyurdukları bir olayla ya da bir köşe yazısı ile sorumluları harekete geçirmişler, hatta bunların Mecliste tartışılmasını sağlamışlardır. Örneğin Türkiye gazetesinde Bir Kürt imzası ile yazılan “İssan Tavuk mudur” başlıklı haber oldukça ses getirmiştir:

"İnsan Tavuk mudur?

Sivas ile Kayseri arasında Kayseri'ye 6 saat mesafede Palas isminde müdürlük, bir köy vardır. Sekenesi 300 haneden ibarettir. Bu köyün civarı bataklıklarla malamaldır. Malarya yani hummay-ı merzagi (bataklık) hastalı̆̆ı. Bizim sıtma dediğimiz hastalık burada o derecede müthiş bir surette icra-i hükm ediyor ki bu sene bu hastalığın mevsim-i tahribi olan iki üç ay zarfında 80 kişi telef olmuştur. 300 haneli bir köyde 80 vatandaş telef olması adi bir vaka, adi bir mesele değildir itikadındayım. Sivas'tan Kayseri'ye kadar 36 saatlik bir mesafe vardır. Bu mesafe üzerinde Bünyan Hamit ve Şehr-i Kışla kazalarıyla birçok köyler ve nahiyeler vardır. Bütün bu mesafede tek bir tabip yoktur!... Bizim vatandaşlarımızın bir kısmı açlıktan, bir kısmı humma-i merzagiden, bir kısmı da frengi hastalığından kırılıp gidiyor. Hükümet ki milletin adeta babası olmak lazımdır, bu zayiat-ı mütemadiye-i müthişeye karşı ne tedbir ittihazetmiştir göstersin. Kastamonu'daki frengi seyyar tabiplerin bulunduğunu bilmiyor değiliz. Fakat bunların ne kadar sudan olduğunu da biliyoruz. Ben misal olarak yalnız Palas'ı zikrettim. Anadolu'da birkaç bin nüfuslu iken şimdi nüfusu 13 (onüç) kişiye tenzil etmiş çok köyler biliriz. Buralarda sülfato (sıtma için kinin) ismi işitilmemiştir. Buralarda bataklık kurutmak nedir bilinmez. Bir tavukçunun tavuklarına bu derecede bir kırgın düşse hükümetin bu insan kırgınına karşı gösterdiği lakaytlık kadar lakaytlık göstermez. Fakat insan tavuk değildir." ${ }^{37}$

${ }^{36}$ MMZC. C: 6, D: 1, İ: 102, s.714.

${ }^{37}$ Türkiye, "İnsan Tavuk mudur", No: 4, 30 Ekim 1910. 
$\mathrm{Bu}$ yazı yayınlandıktan sonra olay ihbar kabul edilmiş ve Dahiliye Nezareti tarafından Palas köyüne araştırma heyeti eşliğinde bir doktor ve kinin gönderilmesi kararı alınmıştır. ${ }^{38}$

Sabah gazetesinde ise Bursa'da yaşanan sıtma kaynaklı ölümlerle ilgili yapılan bir haberde hastalık için önlem alınmadığı ve bölgedeki Ermenilerin durumu Patrikhane'ye yazarak seslerini duyurdukları yer almaktadır. ${ }^{39}$ Karahisar Mebusu Rıza Paşa da Meclis-i Mebusan'da pirinç tarımı ve sulak arazilerin varlığından kaynaklı hastalıklar üzerine yaptığı konuşmada gazetenin bu haberini okumuş ve durumun ciddiye alınması gerektiğini belirtmiştir. ${ }^{40}$

Basında salgınlarla mücadeledeki eksikliklerin yanı sıra uygulamalarda gerekli hassasiyetlerin gösterilmemesi de eleştirilir. 9 Aralık 1912 tarihli Sabah gazetesinde Şehremanetine hitaben "Böyle mi olmalı?" başlıklı bir yazı yayınlanmıştır. Yazıda, Hoca Paşa Hamamı Sokağı'nda bir kahvenin üstündeki odalardan birinde ikamet eden bir adamın kolera olması üzerine arabaya kadar bir hamal tarafından taşındığ 1 ve hamalın hiçbir sıhhi temizlik yapmadan tekrar kahveye döndüğü belirtilmektedir. ${ }^{41}$ Ertesi günkü sayıda Şehremaneti İdare-i Sihhıye Riyaseti'nden gazeteye gönderilen cevap yayınlanır. Cevapta yapılan tahkikatta hastayı taşıyan kişinin hamal olmadığ 1 , iş elbisesini giyen, işi bittikten sonra bu elbiseyi sıcak buharla temizleyen bir memur olduğu ve hastayı götürdükten sonra geri dönüp gerekenleri usulüne uygun olarak yaptığı belirtilir. Gazete ise bu cevaba karşlık "bu vaka üzerine tekrar tahkikat icra ettik... daha hastahaneye vasıl olmadan vefat eden mezkur hastayı odasından aşağı indiren adam kahvecinin çıră̆ı Seyit Ahmet'tir. Hastahaneye götüren de mezkur kahvede ikamet eden aşçı esnafindan Süleyman Ağa'dır. Acaba bunlardan hangisi iş elbisesini labes (giymiş) mubahhar (buhara tutulmuş) idi?" diyerek Şehremaneti’nin doğruyu söylemediğini ileri sürer. ${ }^{42}$ Bu haberin hemen altına bir vatandaştan gelen bilgi paylaşılır: Pendik'te Sarrafoğlu Anarkiros'un damadı Ligoraki beş gün önce Tavuk Pazarı'nda bakkal dükkânında hastalanır. Tedavisine bakılamaz. Cumartesi günü iki kişinin refakatinde acılar içinde dükkândan Pendik'teki evine nakledilir. Mahallesindeki tek belediye çavuşuna haber verilir ve hemen doktor getirilerek muayene edilir ve kolera olmadığı söylenir. Kayınpederi ise kolera olduğunu iddia eder ev karantinaya alınır. Evvelki gün Ligoraki vefat eder. Gazete bu kez de koleralı bir hastanın nasıl olup da Tavuk Pazarı'ndan Pendik'e kadar herkesle temas ede ede gitmesine müsaade olunduğu yetkililere sormaktadır.

Gerek Meclis-i Mebusan'daki tartışmalar gerekse basına yansıyan bu haberler mali durumun yetersizliği ve teknik olanaksızlıklar nedeniyle devletin salgın hastalıklarla yeterince mücadele edemediğini göstermektedir. Bu durum alınan önlemlerin ve yapılan düzenlemelerin başarılı olmasını da engellemektedir.

\footnotetext{
${ }^{38}$ DH. İD. 50-56.

${ }^{39}$ Sabah, No: 7311, 29 Ocak 1910.

${ }^{40}$ MMZC. C: 2 D: 1 İ: 33: s.76.

${ }^{41}$ Sabah, No: 8342, 12 Aralik 1912.

${ }^{42}$ Sabah, No: 8343, 10 Aralık 1912.
} 


\section{Salgınlar ve Eğitim Kurumları}

Salgın hastalıklardan en fazla etkilenen alanlardan biri de eğitimdir. Eğitim toplu halde sürdürülen bir eylemdir; bu nedenle eğitim mekanlarında gerekli hijyen koşullarının sağlanması her dönem sorun olmuştur. Bu zorluk, özellikle ilk kademe eğitim kurumlarında daha da artmaktadır. Salgın dönemlerinde ilk akla gelen önlemler okulların tatil edilmesi, hijyen kurallarının titizlikle uygulaması ve aşılama olmuştur. Osmanlı Devleti'nde bu önlemlerle ilgili yetki Hıfzıssıhha Mekatib Komisyonu ile Mekatib-i Hususiye Müfettişliği'ne verilmiştir. 1908'de İstanbul'da görülen salgınlarda okulların temizliğine daha fazla dikkat edilmesi ve öğrencilere kaynatılmış su içirilmesi gerekliliği okullara bildirilmiş, bu nedenle İstanbul'daki 280 okul için birer semaver alınması amacıyla Maarif Nezareti'ne 10 bin kuruş bütçe ayrıldığı belirtilmiştir. ${ }^{43}$

Okulların bir kısmının veya tamamının, belli bir süre veya tehlike geçene kadar kapatılması salgın dönemlerinde en yaygın başvurulan önlemdir. 1908'de Kadıköy Hamidiye Erkek Mektebi ve Erenköy Rüşdiye Mektebi’nde kabakulak, kızamık, kuş palazı gibi hastalıklar yayılmış, bu iki okul on iki gün tatil edilmiş ve bu okullarda dezenfekte işlemi yapılmasına karar verilmiştir. ${ }^{44}$ Salgın döneminde okulların dönem dönem dezenfekte edilmesi yaygın bir uygulama olarak görülmektedir. ${ }^{45}$ Çocukları etkileyen hastalıkların öldürücü etkisi de kolera ve veba gibi yüksek olabiliyordu. 1909 yılında Bursa Valiliği tarafından Dâhiliye Nezareti’ne gönderilen yazıda iki buçuk aydan beri Gemlik'te devam eden kızıl hastalığından dolayı on dokuz çocuğun hayatını kaybettiği belirtilmiştir. ${ }^{46}$

Kolera salgınlarının yaşandığı dönemlerde hem devlet okulları hem de özel okullar hastalık geçene kadar tatil edilmiştir. Üstelik bu tatil esnasında izdihama neden olacak her türlü merasim yasaklanmıştır. ${ }^{47}$ Bununla beraber okul dişında kalabalığa neden olan toplantıların da yasaklandığı görülmektedir. Örneğin, 1910 yılında, İstanbul'da yaşanan kolera salgını şiddetlenince Kumkapı'daki Kız Mektebi salonunda yapılması planlanan sağlık ve temizlik konulu konferans ile Sosyal Demokrat Hınçakyan Komitesi'nin kuruluş yıldönümü nedeniyle düzenlenecek toplantıya Dahiliye Nezareti izin vermemiştir. ${ }^{48}$

\section{Salgınlar ve Hapishaneler}

Salgın dönemlerinde en riskli yerlerden biri de hapishaneler olmuştur. Hapishaneler genel olarak kalabalıktı; rutubet ve temizlik sorunları nedeniyle normal zamanlarda dahi ciddi sağlık sorunlarına yol açma potansiyeline sahipti. ${ }^{49}$ Bunlara salgın

\footnotetext{
${ }^{43}$ MF. IBT 295-13.

${ }^{44}$ MF. MKT. 1041-14.

${ }^{45}$ MF. IBT. 204-27.

${ }^{46} \mathrm{DH}$. MUİ. 1-32.

${ }^{47}$ MF. MKT 1178-58.

${ }^{48}$ DH. EUM. THR 98-95.

${ }^{49}$ 1909-1914 arasında Anadolu’yu dolaşarak yazdığı yazılar Tanin Gazetesi’nde yayınlayan Ahmet Şerif Bey dolaştığı hapishanelerden de bilgiler aktarır. Anadolu'daki hapishanelerin genellikle rutubetli ve pis yerler olduğunu dile getirirken pek nadir olarak düzenli hapishaneler gördüğünden bahsetmektedir (Gazel, 2005: 150).
} 
hastalıklar da eklendiğinde risk daha çok artıyordu. Bu nedenle salgın zamanlarında ek önlemler alınması gerekmiştir. Örneğin, mahkûm sayısının fazla olduğu hapishanelerde salgın baş gösterir göstermez daha geniş yerler kiralanır, böylece koğuş sayıları artırılarak temas ihtimali azaltılırdı. ${ }^{50}$ Yine salgın zamanı kalabalık hapishanelerde hafif suçlardan tutuklu bulunan kişilerin mahkemeleri öne alınır ve mevcudun azaltılması yoluna gidilirdi. Örneğin, 1918-1920 yılları arasında dünya nüfusunun üçte birini etkileyen İspanyol Gribi imparatorluk başkenti İstanbul'da da görülünce, vali Süleyman Kâni Bey Dâhiliye Nezareti'ne mahkemelerin hızlandırılması talebini iletmiştir. ${ }^{51}$

Salgın dönemlerinde hastalanan tutuklu ve hükümlüler için hapishanenin bir kısmının hastane haline getirilmesi de bir uygulama olarak zaman zaman kullanılmıştır. Örneğin 1914 yılında Tokat Hapishanesi'nde 70 mahkûm tifoya yakalanmış, birkaç gün içinde on yedi mahkûm hayatını kaybetmiştir. Diğer hasta mahkûmların dışarı çıkarılmasının yaratacağı risk göz önüne alınarak hapishanenin uygun kısımları hastaneye çevrilmiştir. ${ }^{52}$

Mahkûmların maddi durumlarının kötü olması, yatak, yorgan, yiyecek yetersizliği hastalığın yayılım ve artış hızını yükseltmiştir. ${ }^{53} 1914$ yılında İstanbul Hapishane-i Umumisi'nde uyuz ve kolera baş gösterdiği zaman fakir mahkûmlara yeni elbise dağıtılması, hamamın tamiri, temiz suyun akmasının sağlanması ve hapishaneye sevk edilen mahkûmların önce tevkifhanede karantina altında tutulması gibi usuller uygulanmıştır. ${ }^{54}$ Fiziksel aksaklıkların tadilatla giderilemeyeceği durumlarda ise sağlık şartlarına uygun olarak hapishanelerin yeniden inşa edilmesi gerekliliği gündeme gelmiş, ancak devletin mali durumu bu tip yeniliklere pek olanak vermemiştir. $^{55}$

Kısacası hapishaneler, kalabalıkları, topluca birlikte bulunma zorunluluğu ve temizlik eksikliği gibi sorunlar yüzünden salgın dönemlerinde dikkatle izlenmişlerdir. Hapishane mekânlarının, salgın dönemlerinde farklı yöntemlerle kontrol edilmeye çalışıldığı, buralardaki mahkûmların hastalıktan en az düzeyde etkilenmesi için büyük gayretler sarf edildiği anlaşılmaktadır.

\section{Salgınlar ve Ticari Hayat}

Salgın hastalıkların yayılmasında çok büyük rolü olan ticaret sektörü, alışverişin yavaşlamasına bağlı olarak zora düşen ekonomi nedeniyle salgın dönemlerinde hayli zarar görmüştür. Üretim azaldığı gibi kamusal harcamalar da artış göstermiştir. Bunun sonucu olarak devlet ek bütçe ya da geçici bütçe hazırlayarak olumsuz etkileri azaltmaya çalışmıştır. Mevcut kayıtlar, Osmanlı döneminde bu yöntemle bütçe oluşturularak salgınla mücadele edildiğini göstermektedir. ${ }^{56}$ Ancak önlem

\footnotetext{
${ }^{50}$ DH. MB. HPS. 6-23; 45-11.

${ }^{51}$ DH. MB. HPS. 79-22.

${ }^{52}$ DH. MB. HBS. 6-17.

${ }^{53}$ DH. MB. HPS. 98-40.

${ }^{54}$ DH. MB. HPS. 72-26.

${ }_{55}^{5 H}$ DH. MB. HPS 75-8.

${ }^{56}$ DH. MUİ. $148-40$.
} 
amaçlı geçici bütçeler de çoğunlukla salgınla mücadelede yetersiz kalmıştır. Dâhiliye Nezareti, 1911 yılında yerel yönetimlere bir yazı göndermiş, bazı kazalarda sulara lağımların karıştığını, bunun çeşitli hastalıklara ve özellikle koleraya neden olduğunu, bu sorunun giderilmesi için suların demir borularla akıtılması ve lağım mecralarının tamir edilmesi gerektiğini bildirmiştir. Ancak tamir için hükümete nakit yardım yapması yönündeki müracaatların sayısı çok fazla olunca kolera münasebetiyle büyük masraflar yapan hazinenin suyolları ve lağımlar için yerel yönetimlere yardıma tahammülü olmadı̆̆ı belirtilir. Bu nedenle tamirat ve inşaat ihtiyacı hisseden mahallerde idare ve belediye meclisleri tarafından öncelikle halktan para toplanması yoluna gidilmesi, eğer yetmezse hazineden talep edilmesi istenir. ${ }^{57}$ Suyun halka temiz bir şekilde ulaşması ve kanalizasyon sistemlerinin kapalı olması salgınlarla mücadelede önemli unsurlar olarak bilinir. Ancak ekonomik koşullar nedeniyle imparatorluğun bu konuda yeterli önlemleri alabildiğini söylemek mümkün değildir.

Salgınlar zaten ekonomik olarak sıkıntı içinde olan Osmanlı mali sistemine daha büyük yükler getirmiş, bu da temel kamusal sorumlulukların yerine getirilmesini zorlaştırmıştır. Örneğin, kolera salgını döneminde tedbir amaçlı okulların kapatılması, genel olarak problem yaratmanın ötesinde özellikle özel okul çalışanlarına ek sorunlar çıkarmıştır. Salgın dönemlerinde, öğretmen ve müstahdemlerinin maaşlarını ödemede güçlük çeken özel okullar merkezi idareden bu konuda yardım talep etmişlerdir. Ancak mali durum devletin bu konuda adımlar atmasını zorlaştırmıştır. Nitekim bu tür yardım taleplerine olumsuz cevap verildiğine yönelik kayıtlar vardır. ${ }^{58}$ Yine 1910 yılı kolera salgını sırasında, İstanbul'da, Askeri Rüşdiye Mektepleri kantinlerinin işletmecileri Mektepler Müdüriyet-i Umumiyesi’ne başvurarak 500-600 kuruş kira ödediklerini, kolera nedeniyle yiyecek ve içecek satışında kısıtlanmaya gidildiği için sadece ekmek peynir satabildiklerini, bu nedenle kazançlarının düştüğünü ve kiralarında indirim yapılması gerektiğini talep etmişlerdir. Ne var ki kendilerine, kiraların zaten uygun olduğu ve herhangi bir indirimin söz konusu olamayacağı bildirilmiştir. ${ }^{59}$

Salgın dönemlerinde alınan önlemlerden en çok esnaf mağdur olmuştur. Esnafın sık sık devlete başvurup mağduriyetinin giderilmesi konusunda taleplerde bulunması oldukça yaygındır. Örneğin, 1911'de kolera nedeniyle hıyar (salatalık) mahsulünün satışının yasaklanması üzerine zarara uğradıklarını belirten bostancı esnafı adına Abduh Dede ve Şerif imzasıyla verilen dilekçede zararlarının karşılanması istenmiş ancak bu istek kabul edilmemiştir. ${ }^{60}$ Yine ertesi yıl Kayseri'de kolera hastalığı nedeniyle tedbir amaçlı olarak hayvanların kesilmesi ve pastırma yapılması yasaklanmıştır. Buna rağmen bazı etlikçi esnafı, kanuna rağmen hayvan kesip pastırma yaptığı için cezalandırılmıştır. ${ }^{61}$ Ayvansaray'da Osman adında bir kayıkçının koleradan ölmesi üzerine Haliç ve Boğaziçi sahillerindeki bazı bölgelerden midye ve istiridye toplanmış, tahlil edilmiş, pek çoğunda mikrop ve kolera vibriyonlarına benzer virüsler tespit edilmiştir. Bu nedenle, halk sağlı̆̆ını korumak

${ }^{57}$ DH. MB. HPS. M. 2-37.

${ }^{58}$ BEO. 3839-287898.

${ }^{59}$ ML. EEM. 849-41.

${ }^{60}$ DH. İD. 53-24.

${ }^{61}$ DH. İD. 38-15. 
adına sahillerde istiridye ve midye yetiştirilmesi ve çıkarılması kesinlikle yasaklanmıştır. ${ }^{62}$

Salgınlar ulaşım faaliyetlerini de olumsuz yönde etkilemekteydi. 1913 yılında, kolera yüzünden Yalova-İstanbul arası vapur seferleri durdurulunca, İstanbul ile başka bir ulaşım imkânı olmayan Yalova'da ticaret zarar görmüş, ahalinin çoğu işlerini halledemediğinden yakınmıştır. Pek çok kişi, önceki yıl da kolera salgını olmasına rağmen böyle bir uygulamaya gidilmediğini, bu yılki uygulamaya anlam verilemediğini belirtmiş, seferlerin yeniden başlaması için talepte bulunulmuş, bu talepleri İzmit Mutasarrıflığından Dâhiliye Nezareti'ne iletilmiştir. ${ }^{63}$

Bulgaristan ve Osmanlı arasında ortak kullanılan tarım alanlarıyla ilgili olarak karşılıklı bir anlaşma yapılmıştır. Ancak kolerayı gerekçe gösteren Bulgaristan kendi tarafındaki pek çok su kaynağını kapatmış ve Bakorin mıntıkasında hastalık olmamasına rağmen karışık arazi sahiplerinin ekinlerini biçmeleri için izin vermemiştir. Zaten fakir olan ahalinin bu durumda büyük zarara uğradığı ve gereken adımların atılması için gereğinin yapılması, Hariciye Nezareti'nden Sofya elçiliğine bildirilmiştir. $^{64}$

\section{Salgınlar ve Askeriye}

Salgın dönemlerinde gözlerin çevrildiği kurumların başında gelen bir diğer kurum askeriyedir. Buralarda birlikte yaşam kesintisiz biçimde 24 saat devam ettiği için hastalık riski diğer alanlardan daha yüksek olmuştur. Salgın dönemlerinde eğitime ara vermek gibi bir seçenek mümkün olmadığı için süreci idare etmek daha da güçleştirmektedir. Bu yüzden, farklı toplumsal sinıflardan ve coğrafyalardan gelen, belki de yaşadıkları yerlerden hastalık taşıyan binlerce askerin topluca yaşadığı kışlalarda, hijyen sağlamak ya da temizlik işlerini sürdürmek her zaman sorun olmuştur. 19. yüzyıl boyunca ve 20. yüzyılın başlarında Anadolu'da görülen ciddi salgınlar, aynı dönemlerde yaşanan pek çok savaşla birleşince bulaşma riski katlanarak artmıştır. Kimi savaşlarda hastalık nedeni ile ölen asker sayısının ciddi boyutlara ulaştığı bilinmektedir. Örneğin, 1853-1856 Kırım Savaşı sırasında sadece hastalıktan ölen İngiliz, Fransız, Osmanlı ve Rus askerlerinin toplamı 500 bin civarındadir. ${ }^{65}$

Aynı şekilde, 1910 yılında, Rusya'da başlayan kolera salgınının Karadeniz limanlarından geçişi önlenememiştir. ${ }^{66}$ Koleranın önce Trabzon'da görüldüğü, sonra Sinop'taki Redif Taburlarına bulaştığı, en sonunda da tatbikat için İstanbul Hasköy’e getirilen bu taburlar aracılığı ile tüm şehre yayıldığı iddia edilmiş, bu konuyla ilgili Meclis-i Mebusan'da sert tartışmalar yapılmıştır. Dâhiliye Nazırı Talat Bey, hastalığın Sinop Taburlarından geldiği iddialarına karşı çıkmış ancak bazı vekilleri ikna edememiştir. ${ }^{67}$ Dahası hastalığın bir biçimde yayıldığı bilindiği halde gerekli ted-

\footnotetext{
${ }^{62}$ DH. MKT. 1239-1.

${ }^{63}$ DH. İD. 197-5.

${ }^{64}$ HR. SFR.04., 682-84.

${ }^{65}$ Özdemir, Salgın Hastaliklardan, s.53.

${ }^{66}$ MMZC. C: 1, D: 1 İ: 6, s.129.

${ }^{67}$ MMZC. C: 1, D: 1 İ: 6, s.132-133.
} 
birler alınmadan planlanan ve 1910 yılı sonbaharında Edirne'de yapılan askeri tatbikat da tartışma konusu olmuştur. Tatbikat sırasında başlayan kolera salgını sebebiyle hayatını kaybeden asker sayısının hayli yüksek olduğu anlaşılmıştır. Zöhrab Efendi ve Arif Hikmet Bey gibi vekiller, tatbikatın neden ertelenmediğini sormuşlar, kolera salgını bilindiği halde askerlerin göz göre göre ölüme gönderildiğini iddia etmişlerdir. Sadrazam İbrahim Hakkı Paşa ise, tatbikat başlamadan önce İstanbul'daki salgının bittiğini, Edirne'ye gönderilen askerler arasında kolera vakasının görülmediğini, tatbikatın başında bile hasta kimse olmadığını savunmuş, salgının birdenbire başladığını ve sebebini bilemediklerini ifade etmiştir. ${ }^{68}$

Salgın nedeniyle memleketlerine gönderilemeyen askerler için Sihhiye İdaresi'nde bulunan karantinahanelerin her birinde dört beş bin kişi barındırabilecek barakalar ve birkaç yüz kişilik binalar yapılması gerekliliği Sadrazamlık'tan Sıhhiye Nezareti'ne bildirilmiştir, ${ }^{69}$ terhisleri yapılamayan askerler için tedavinin ve salgının bitmesi beklenmiştir. Askerlerin kışlaları ise ayrı bir sorun oluşturmuştur. İstanbul ve civarındaki kışlaların durumlarının düzeltilmesi için düzenlemelerin genellikle hızlı yapıldığı, Anadolu'daki, özellikle de Doğu Anadolu'daki kışlaların ise kapasite yetersizliği ve temizlik sorunları hemen çözülemediği için hayli sıkıntı yaşadıkları belirtilmektedir. ${ }^{70}$

Özellikle Balkan Savaşları ve I. Dünya Savaşı'nda salgının yayılma hızı ve etkisi açık bir şekilde görülmektedir. 1913 yılında Bulgar ordusunda başlayan koleranın 25 bin askere bulaştığı tahmin edilmektedir. Yeterli tıbbi gereçler olmadığından bu salgında çok fazla ölüm yaşanmıştır. Bu nedenle, Bulgar Krallığı tarafından Viyana Tıp Fakültesi doktorları davet edilmiş, tetkikler yaptırılmıştır. Ayrıca Viyana'da, Kızılhaç öncülügüunde kolera başta olmak üzere askerler arasında yaygın görülen hastalıklarla ilgili olarak bir konferans düzenlenmesi kararlaştırılmıştır. Pek çok ülkenin Kızılhaç örgütlerinin katılacağı bu organizasyonda Osmanlı Devleti de temsil edilmiştir. ${ }^{71}$ Özellikle Balkan Savaşları’nda, Osmanlı askerlerinde görülen koleranın şiddeti, dahası, cephede başlayan bu salgının Edirne ve İstanbul'a kadar sıçrayarak sivil halkı da etkilemesi Osmanlı yönetimini harekete geçirmiş, Kızılay’dan bir heyetin Viyana'ya gönderilmesi kararlaştırılmıştır.

Dört yıl süren I. Dünya Savaşı'nda ise, pek çok cepheye dağılan Osmanlı askerleri savaş felaketi ve yetersiz beslenme, susuzluk, esirlik, temizlik, ilaç yokluğu gibi zorlukların yanında hastalıklarla da boğuşmak zorunda kalmıştır. Osmanlı askerleri arasında hastalık kaynaklı ölüm oranı oldukça yüksektir. Tablo 2 ve Tablo 3 'te, savaş boyunca hastalıktan ölen asker sayıları ve tespit edilen bazı hastalıklarla buna bağlı ölümler görülmektedir.

\footnotetext{
${ }^{68}$ MMZC. C: 1, D: 1 İ: 6, s.134-136..

${ }^{69}$ BEO. 3843-288198.

${ }^{70}$ MMZC. C: 4, D: 1, İ: 61, s.159.

${ }^{71}$ BEO. 4228-317038.
} 
Tablo 2. I. Dünya Savaşı’nda Osmanlı Ordusunda Hastalıktan Ölen Asker Sayısı ${ }^{72}$

\begin{tabular}{|l|l|}
\hline Yillar & Hastalıktan Ölüm \\
\hline Savaşin 1. Y11ı & 57,462 \\
\hline Savaşı 2. Y11 & 126,216 \\
\hline Savaşın 3. Y11 & 133,469 \\
\hline Savaşin 4. Y11 & 84,712 \\
\hline Toplam & 401,859 \\
\hline
\end{tabular}

Tablo 3. I. Dünya Savaşı’nda Osmanlı Ordusunda Tespit Edilen Bazı Vaka ve Ölümler ${ }^{73}$

\begin{tabular}{|l|l|l|}
\hline Hastalık & Ölümler & Vaka Sayısı \\
\hline Sitma & 23,351 & 461,799 \\
\hline Dizanteri & 40,000 & 147,000 \\
\hline Dönüşlü Ateş & 4,000 & 103,000 \\
\hline Tifüs & 26,000 & 93,000 \\
\hline Frengi & 150 & 27,000 \\
\hline
\end{tabular}

Savaşlardaki hastalık kaynaklı ölümler dönemin üst rütbeli subaylarında da görülmüştür. II. Abdülhamit zamanında Osmanlı ordusunun modernizasyonu için Almanya'dan getirtilen ve I. Dünya Savaşı'nda Osmanlı ordusunda kurmay başkanlığı görevini de yürüten Von der Goltz Paşa Bağdat'ta cephede yakalandığı tifüs hastalığı nedeni ile hayatını kaybetmiştir. ${ }^{74}$ İkdam Gazetesi haberi birinci sayfadan Büyük Von der Goltz’un Vefatı başlı̆̆ ile duyurmuştur. ${ }^{75}$ Tifüsten hayatını kaybeden bir diğer general de Enver Paşa'nın Harbiye'den sınıf arkadaşı, Sarıkamış Harekâtı'nın da önemli komutanlarından biri olan Hafız Hakkı Paşa'dır. Doğu Cephesi'ndeki ağır yenilgiden kısa süre sonra 3. Ordu Komutanı olarak görev yaptığı Erzurum'da tifüsten yaşamını yitirmiştir. ${ }^{76}$

Salgın, özellikle esir kamplarında çok hızlı bulaşmaktaydı. Bu kamplarda gerek Osmanlı gerekse Osmanlı'nın esir aldığı askerler arasında hastalıklar yüzünden hayatını kaybeden çok sayıda asker vardır. Osmanlı topraklarında bulunan esir kamplarında İngiliz, Fransız ve Rumen esir askerlerle ilgili pek çok yazışma yapıldığı arşiv belgelerinde bulunmaktadır. 1917'de, Kütahya'da bir iki köyde esir tutulan Romanya askerlerinin bir kısmı tifodan hayatını kaybedince İspanya Büyükelçiliği kalan askerlerin başka tarafa nakillerini talep etmiştir. ${ }^{77}$ İki askerinden sağlıklı bilgi alamayan İngiltere'nin isteği üzerine gönderilen bir yazıda, Başçavuş William Smith'in 30 Nisan 1917'de lekeli humma hastalı̆̆ından Davut Paşa Hastanesi'nde vefat ettiği, diğer asker James Smith'in ise hayatta olup Samatya esir garnizonunda olduğu belirtilmektedir. ${ }^{78}$ James Mayol adlı bir başka İngiliz esirinin, 17 Şubat

72 Özdemir, Salgin Hastalıklardan, s.136.

${ }^{73}$ Özdemir, Salgin Hastalıklardan, s.137.

${ }^{74}$ HR. MTV. 768-14.

${ }^{75}$ İkdam, No: 6895, 23 Nisan 1916.

${ }^{76}$ DH. ŞFR. 461-64.

${ }^{77}$ HR. SYS. 2224-45.

${ }^{78}$ HR. SYS. 2225-18. 
1917'de Ankara Kurbağalı civarında lekeli humma hastalığı nedeniyle vefat ettiği, ardından bu mahalde bir mezarlığa defnedildiği ve usulüne uygun olarak hazırlanan vefat bildirim belgesinin Hilal-i Ahmer Cemiyeti'ne gönderildiği bildirilmiştir. $^{79}$

Savaşa katılmayan ülkelerin, savaşan taraflardaki esirler için aracı olduğu ve bazı konuları çözmek için kendilerinden yardım istendiği görülmektedir. Örneğin Osmanlı Devleti'nin elinde esir bulunan Jean Beauvoir, François Herlo, Le Pare ve Seizie adındaki dört Fransız subay için Papalık devreye girmiştir. Papalığın İstanbul temsilcisi Monsenyör Dolci, humma hastalığına yakalanan bu subayların tedavisi için İsviçre'ye gönderilmelerini istemiştir. Hatta Enver Paşa'nın Hariciye Nezareti'ne bu konuda yardımcı olmaları için bir yazı yazdığı iddia edilmektedir. Ancak Enver Paşa, bu vaadini hatırlamadığını ama Papalık makamına olan saygılarından dolayı daha önce birkaç Fransız subayını ülkelerine gönderdiklerini fakat karşı tarafın hiçbir Osmanlı esirini tedavi için ne İsviçre'ye ne de Türkiye'ye göndermediğini belirtir. ${ }^{80}$

\section{Sonuç}

İnsanlık tarihinde, savaşlar ve büyük göçlerin yanı sıra salgın hastalıklar da toplumları kitlesel olarak etkilemiştir. 2020 yılının başından itibaren dünyayı etkisi altına alan Covid-19 salgını şimdiden 21. yüzyılın en önemli olayları arasına girmiş bulunmaktadır. Tıpkı Ortaçağ' daki veba gibi insanların evlerine kapanmasına ve ölüm endişesi içinde yaşamasına neden olmuş, dahası, sonuçları yavaş yavaş ortaya çıkmaya başlayan sosyo-ekonomik yıkımların önünü açmıştır.

Covid-19 salgını için alınan önlemler, bir asır önceki salgınlarda kullanılan yöntemlerle benzerdir; hatta birebir aynı olduğu bile söylenebilir: Karantina uygulaması, sınırların kapatılması, okulların tatil edilmesi, kalabalığa neden olacak etkinliklerin yasaklanması, başta el yıkama olmak üzere kişisel temizliğin sürekli tavsiye edilmesi, ulaşımda kısıtlama getirilmesi, bazı ürünlerin satışının yasaklanması, tarihin salgın hastalıklarla ilgili deneyimlere dayalı hikayelerinin aynı şekilde "tekerrür ettiğini” göstermektedir. Öte yandan, tıpkı Osmanlı Dönemi salgınlarında olduğu gibi Covid-19 salgınında da neredeyse aynı ekonomik sıkıntıların yaşandığı görülmektedir. Kirasını ve vergisini ödemekte zorlanan esnaf, maaşlarını kaybettiği için ekonomik darboğaza düşen çalışanlar, devlet desteğine ihtiyaç duyan işletmeler ve daha başka pek çok sıkıntı bu benzerliğin nitelik değiştirmiş yansımalarından başka bir şey değildir.

Özetle, Osmanlı Devleti birçok salgın hastalığın yıkıcı etkisini yakından hissetmiştir. II. Meşrutiyet döneminin her alanda yarattığı değişimlere Trablusgarp Savaşı ile başlayan savaşlar eşlik edince ekonomik ve sosyal sorunlar daha da artmış, uzun zamandır ekonomik bunalımın acılarını yaşayan halk iyice zor duruma düşmüştür. Bir yandan, kaybedilen topraklardan Anadolu'ya başlayan göç dalgası diğer yandan etnik gruplar arasında yaşanan gerilimler toplumsal düzeni iyice alt üst etmiştir. Ülkenin pek çok yerinde yoksulluk neredeyse sıradan bir hal almıştır. Nüfusun

${ }^{79}$ HR. SYS. 2261-20.

${ }^{80}$ HR. SYS. $2225-36$. 
büyük bir kısmı bakımsızlıktan ve salgın hastalıklardan kırılmaktadır; özellikle hastalık kaynaklı ölüm oranları oldukça yüksektir. Öteden beri var olan verem, çiçek, dizanteri gibi hastalıklara dış kaynaklı veba ve kolera gibi çok öldürücü salgınlar da eklenince tahribat trajik düzeylere çıkmıştır.

İmparatorluğun son yüz yıllık döneminde en çok korkulan hastalık olan kolera olmuştur. Veremden ölenlerin sayısı koleradan ölenlerin sayısını üçe katlamasına rağmen kolera daha büyük bir tehdit olarak görülmüş, adının duyulması bile, devletin hemen önlemlere girişmesi için yeterli sayılmıştır. Okulların tatil edilmesi, kalabalık toplantıların ertelenmesi, yurt dışından gelen gemi ve kafilelerin karantinaya alınması, hastalığın görüldüğü yerlerde dezenfekte çalışmalarının yapılması gibi tedbir amaçlı adımlar hemen atılmıştır. Ancak temel altyapı sorunları nedeniyle salgınlarla baş etmekte çok zorluklar çekilmiştir. Ülkenin pek çok yerinde hastane ve sağlık personeli eksikliği bulunmaktadır. Ayrıca temiz içme suyunun demir borularla taşınması ve kanalizasyon sistemlerinin yapılması gibi işler için devlet bütçesi hiçbir zaman yeterli olmamıştır.

Cezaevi, askeriye, okul gibi insanların toplu halde bulunduğu mekanlar her türlü salgın için risk oluşturmuştur. Özellikle cezaevi ve kışlaların durumu sağlık açısından hiç de elverişli değildir. Bakımsız binaların yerine yeni binaların yapılması defalarca gündeme gelmiş olmasına rağmen ödenek yetersizliği, bunun hayata geçmesini mümkün kılmamıştır. Özellikle savaş dönemlerinde, asker arasında salgınlar normal zamanla kıyaslanmayacak ölçüde artmıştır. II. Meşrutiyet Dönemi, Balkan Savaşları ve I. Dünya Savaşı en yoğun salgın zamanlarıdır. Orduda görülen salgınların zaman zaman sivil halka da bulaştığı görülmüştür.

Salgın hastalıklar kuşkusuz en fazla ekonomide tahribat yaratmıştır. Bu tür zamanlarda tedbir olarak kimi ürünlerin satışının yasaklanması, ulaşım ve ticaretin sınırlandırılması gibi uygulamalar farklı ticari kesimlerin önemli gelir kayıpları yaşamasına neden olmuştur. Salgınların ekonomik hayata verdiği zarar, doğrudan vergi gelirleri üzerinden devleti de etkilemiştir. Vergi gelirlerinde yaşanan düşüşe ek olarak, salgını önlemeye yönelik kamu harcamaları nedeniyle devlet büyük mali yükler altına girmiştir. Zor durumdaki Osmanlı maliyesi, bu yüklerle temel kamusal yükümlülüklerini yerine getirmede oldukça zorlanmıştır. Salgınlarda kaybedilen insan sayısı aynı zamanda üretimde büyük iş gücü kayıplarına yol açmıştır.

Sonuç olarak, geçmişte yaşanan salgınlardaki gibi bugün yaşanılan salgının da ekonomik, sosyal ve siyasal anlamda uzun erimli sonuçlar üretme potansiyeline yatkın olduğu görünmekte ve yakın zamanda gerçekleşecek toplumsal değişim ve dönüşümlerin ateşini yakacak gibi durmaktadır.

\section{Kaynakça}

\section{Cumhurbaşkanlığı Devlet Arşivleri Başkanlığı Osmanlı Arşivi}

A_MTZ.05. 19-112.

BEO. 3839-287898, 3843-288198, 4103-307685, 4228-317038, 4233-317456.

DH. EUM. THR. 98-95.

DH. HMŞ. 14-26. 
DH. İD. 38-15, 50-6, 50-56, 53-24, 197-5.

DH. MB. HPS. 6-17, 6-23, 45-11, 72-26, 75-8, 79-22, 98-40.

DH. MB. HPS. M. 2-37.

DH. MKT. 1239-1, 2617-64 /68, 2615-50, 2650-93

DH. MUİ. 1-32, 3-19, 148-40.

DH. ŞFR. 461-64.

HR. İD. 10-63.

HR. SFR.04. 682-84, 843-26.

HR. SYS. 2224-45, 2225-18, 2225-36, 2261-20.

MF. IBT. 204-27, 295-13.

MF. MKT. 1041-14, 1178-58.

ML. EEM. 849-41.

Meclis-i Mebusan Zabit Cerideleri

MMZC. C: 1, D: 1 İ:6.

MMZC. C: 2, D: 1, İ:29.

MMZC. C: 2, D: 1, İ:33.

MMZC. C: 4, D: 1, İ:61.

MMZC. C: 5, D: 1, İ:83.

MMZC. C: 5, D: 1, İ:75.

MMZC. C: 6, D: 1, İ:102.

\section{Gazeteler}

İkdam, No: 6895.

Sabah, No: 7311, 8343.

Türkiye, No: 4.

Diğer Kaynaklar

Arık, Feda Şamil. “Selçuklular Zamanında Anadolu'da Veba Salgınları”. A.Ü. Tarih Araştırmaları Dergisi. XV/26 (1991): 27-57.

Ayar, Mesut. “Osmanlı Devleti'nde Kolera Salgını: İstanbul Örneği 1892-1895”. Doktora Tezi, Marmara Üniversitesi, 2005.

Castel, Robert. Ücretli Çalışmanın Tarihçesi. Çev., Işık Ergüden. İstanbul: İletişim Yayınları, 2019.

Dersaadet 1330 Senesine Mahsus Sıhhi İstatistiklerdir, Dersaadet 1331, Şehremaneti Sıhhiye Müdüriyeti.

Faroqhi, Suraiya. Osmanlı İmparatorluğu'nda Yollara Düşenler. İstanbul: Kitap Yayınları, 2016.

Faroqhi, Suraiya. “Krizler ve Değişim 1590-1699”. Osmanlı İmparatorluğu’nun Ekonomik ve Sosyal Tarihi 2. Der., Halil İnalcık ve Donald Quataert. İstanbul: Eren Yayınları, 2004.

Gazel, Ahmet Ali. “Tanin Muhabiri Ahmet Şerif Beyin Notlarında Osmanlı Hapishaneleri". Hapishane Kitabı. Der., Emine Gürsoy Naskalli ve Hilal Oytun Altun. İstanbul: Kitabevi Yayınları, 2005. 
Huberman, Leo. Feodal Toplumdan Yirminci Yüzyıla. Çev., Murat Belge. İstanbul: İletişim Yayınları, 1995.

Karaimamoğlu, Tolgahan. "Kara Ölüm Veba Salgını ve Ortaçağ İngiltere’sine Etkileri”. Akademik Sosyal Araştırmalar Dergisi. 37 (2016): 591-610.

Özdemir, Hikmet. Salgın Hastalıklardan Ölümler 1914-1918. Ankara: Türk Tarih Kurumu Yayınları, 2005.

Özden, Kemal ve Özmat, Mustafa. "Salgın ve Kent: 1347 Veba Salgınının Avrupa'da Sosyal, Politik ve Ekonomik Sonuçları”. İdeal Kent Dergisi. 12 (2014): 60-87.

Quataert, Donald. “19. Yüzyıla Genel Bakış: Islahatlar Devri 1812-1914”. Osmanlı İmparatorluğu'nun Ekonomik ve Sosyal Tarihi 2. Der., Halil İnalc1k ve Donald Quataert. İstanbul: Eren Yayınları, 2005: 885-1051.

Roberts, J.M. Avrupa Tarihi. Çev., Fethi Aytuna. İstanbul: İnkılap Yayınları, 2015.

Sakaoğlu, Necdet. Bu Mülkün Sultanları. İstanbul: Alfa Yayınları, 2015.

Solakzade Tarihi. İstanbul: Mahmut Bey Matbaası, 1297.

Tanilli, Server. Yüzyılların Gerçeği ve Mirası İnsanlık Tarihine Giriş: Ortaçăg. İstanbul: Cem Yayınları, 1995.

Topkaya, Özgür. “Sosyal Politika Bağlamında Dünyada Sağlık Politikalarının Tarihsel Gelişimi”. Süleyman Demirel Üniversitesi İktisadi ve İdari Bilimler Fakültesi Dergisi. 21/2 (2016): 707-722.

Turna, Nalan. "İstanbul'un Veba ile İmtihanı: 1811-1812 Veba Salgını Bağlamında Toplum ve Ekonomi”. Studies of the Ottoman Domain. 1/1 (2011): 1-36. 


\title{
The Challenge of Epidemics of an Empire towards Collapse: An Example of the Second Constitution Era
}

\author{
M. EMİN ÇAYCI๋ \\ emincayci@kocaeli.edu.tr \\ ORCID ID: 0000-0003-0381-1936
}

\author{
ABİDİN ÇEVİK* \\ abidin.cevik@kocaeli.edu.tr \\ ORCID ID: 0000-0001-5459-2935
}

\begin{abstract}
The last period of the Ottoman Empire was full of economic crises, wars and internal turmoil, and epidemic diseases were also fought. Trade routes coming through Iran and the Caucasus, returning visitors from the holy lands, ships coming to port cities such as Antalya, Istanbul, Izmir and Trabzon have been effective in the spread of the diseases. In such epidemics, methods such as quarantine application, closing borders and hygiene measures were used to prevent the spread. Medical facilities and general economic situation prevented the struggle to be carried out properly. The struggle, which was carried out with different methods, was criticized in the press and at the political level. The measures taken caused problems in areas such as education, transportation and trade, which led to criticism. In this study Ottoman archive documents were used as the main source, the social effects of the II. Constitutional Era epidemics and the measures taken by local and central administrations were tried to be explained.
\end{abstract}

Keywords: Epidemic, Cholera, Plague, $2^{\text {nd }}$ Constitutional Era, Ottoman Empire

\footnotetext{
* Lect., Kocaeli University, Department of Atatürk's Principles and History of Revolution.

${ }^{* *}$ Lect. Dr., Kocaeli University, Department of Atatürk's Principles and History of Revolution.
} 